\title{
Collections Archives Dealing with Nazi Victims
}

\section{The Example of the Arolsen Archives}

\begin{abstract}
After the Second World War, millions of persons were missing, with relatives, friends and the governments of their home countries searching for them. Knowledge about the crimes committed by the Nazis was still fragmentary. Against this background, a new type of archive emerged that broke with established archival principles: collections archives were created for specific purposes in the period following 1945 - the search for victims and survivors of Nazi persecution, the criminal prosecution of perpetrators or remembrance of the crimes which were committed. This paper uses the history of the Arolsen Archives to examine two issues which, while being relevant to archives in general, were and are particularly important for collections archives. The first of these issues is the collection and organization of documents. The second issue concerns independent research and questions of access to the holdings of collections archives. The intention of this chapter is not only to help readers understand the history of the Arolsen Archives and the structure and usability of their collections, but also to begin to identify the peculiarities and challenges which are particular to this new type of collections archives.
\end{abstract}

\section{Introduction}

In response to Nazi persecution and the turmoil of the Second World War, a new type of archive emerged that broke with established archival principles: collections archives were created by different organizations for specific purposes in the period following 1945. The various activities which these organizations were involved in - the search for missing persons, the criminal prosecution of perpetrators or remembrance of the crimes which were committed - enriched these archives over decades. Later on, many of them were brought closer into line with conventional archives in terms of working practices and some were even integrated into conventional archives. However, certain special features of this new type of archive still endure.

One of the largest of these new collections archives came into being at the International Tracing Service (ITS), now known as the Arolsen Archives, in the 
town of Arolsen in north Hesse, Germany. ${ }^{1}$ However, other tracing bureaus and related institutions also built up similar collections for the purpose of clarifying fates. In Germany, these included the collections of the Tracing Service of the German Red Cross, the Church Tracing Service or the German Office for the Notification of Next of Kin of the Former German Wehrmacht (German acronym: WASt), which was recently taken over by the Federal Archives. A different purpose, criminal prosecution, led to the creation of other collections which were similar in structure. Early examples include the collection built up by Simon Wiesenthal and others at the Jewish Historical Documentation Center in Linz and the collection created by the Main Commission for the Prosecution of Crimes against the Polish Nation in Warsaw; a later addition was the collection set up at the Central office of the Judicial Authorities of the Federal States for the Investigation of National Socialist Crimes in Ludwigsburg, which was established in 1958. By contrast, most modern collections archives were created for the purposes of commemoration and remembrance. Examples include Yad Vashem in Jerusalem, founded in 1953 already, and the United States Holocaust Memorial Museum in Washington, DC, founded in 1993 - alongside the Arolsen Archives, these are probably the largest examples of this new type of archive - but there are also hundreds of other documentation centers and memorial site archives throughout Europe and beyond. ${ }^{2}$

Not only does the founding history of these institutions have a common historical point of reference, their development was intertwined and involved close cooperation which sometimes went as far as to include frequent sharing of collections of original documents or copies of collections. A comprehensive history of the new collections archives is nonetheless a desideratum of historical research. The first difficulty encountered when trying to describe this new type of archive is what to call them - we suggest using the term collections archives. ${ }^{3}$ The institutions of the archiving world are of little help in this respect. Archives of this type are not mentioned in archival manuals, at least not in those which

\footnotetext{
1 On the history of the Arolsen Archives see Henning Borggräfe, Christian Höschler and Isabel Panek (eds.): A Paper Monument: The History of the Arolsen Archives, Exhibition Catalogue, Bad Arolsen: Arolsen Archives, 2019.

2 For an extensive overview of many of the archives which hold Holocaust-related collections, see https://portal.ehri-project.eu/institutions. Last accessed: 12.7.2019.

3 Our thanks go to Christian Groh, Head of Archives at the Arolsen Archives, for his valuable contribution to discussions about this term.
} 
are available in the German language. ${ }^{4}$ The International Council on Archives (ICA) lists the Arolsen Archives under "archives of international organizations" and separates them from the other institutions mentioned above. The Association of German Archivists groups the Arolsen Archives together with the "archives of academic institutions”, a categorization which is equally unhelpful.

This chapter uses the history of the Arolsen Archives to examine two issues which, while being relevant to archives in general, were and are particularly important for collections archives. The first of these issues is the collection and organization of documents, which is interesting for the very reason that the principles of archiving stipulate that the "natural" place for any of the documents in the archive to be would actually be in another archive. The second issue concerns independent research and questions of access, which were challenging because collections archives initially served one specific purpose only, and that purpose did not include historical research or call for external access as a matter of course.

The intention of the present chapter is not only to help readers understand the history of the Arolsen Archives and the structure and usability of their collections, but also to begin to identify the peculiarities and challenges which are particular to this new type of collections archive. In future, it would be desirable to conduct systematic research into the history of these institutions which have emerged since 1945 in connection with the critical analysis of Nazi crimes. This seems important, not least in an epistemological sense, in order to better understand how our modern methods of research, education and remembrance in relation to Nazi crimes and their victims were and are themselves shaped by the new collections archives.

\section{Collecting and Organizing Beyond the Principle of Provenance}

The ITS, now known as the Arolsen Archives, collected more than 30 million originals and copies of documents from concentration camps and prisons, on Nazi forced labor, and on Displaced Persons (DPs) for the purposes of tracing missing persons and clarifying fates, but also to furnish proof of individual persecution for compensation claims, for example. The most important finding aid is an

4 Cf., for example, Norbert Reimann: "Grundfragen und Organisation des Archivwesens", in Norbert Reimann (ed.): Praktische Archivkunde. Ein Leitfaden für Fachangestellte für Medienund Informationsdienste, Fachrichtung Archiv, Münster: Ardey-Verlag, 2014, 25-54, here 36-46. 
enormous Central Name Index which contains more than 50 million reference cards.

Searching for documents and organizing them in such a way that they can be evaluated efficiently in respect of individual persons were the main tasks of the ITS for decades. This approach is, however, extremely questionable from a conventional archival perspective. The reason for this is a basic principle which has been adhered to in the world of archiving for over 100 years, the "principle of provenance: the basic principle that records/archives of the same provenance must not be intermingled with those of any other provenance." ${ }^{5}$ This principle ultimately defines both the area of responsibility of archives - they hold the records of specific bodies - as well as the internal organization of the collections. This principle is of such central importance that it is mentioned in the ICA's Code of Ethics: “Archivists should appraise, select and maintain archival material in its historical, legal and administrative context, thus retaining the principle of provenance, preserving and making evident the original relationships of documents." 6

Adhering to this principle does not, of course, mean that archives simply take hold of history. Every archive and every collection was created in, is part of and marked by specific political and cultural contexts. This also holds true for collections archives like the Arolsen Archives. However, there is also an additional special dimension which applies to collections archives: "[F]or historians using the ITS, teasing out historical meaning is especially challenging. [The sources] are arranged in order to facilitate the tracing process and not historical research."7 Their specific purpose gave rise to various peculiarities which apply to collections archives as opposed to conventional archives. These peculiarities will be described in the following four sections of this chapter using the history of the Arolsen Archives as an illustration.

5 Peter Walne (ed.): Dictionary of Archival Terminologies/Dictionnaire de terminologie archivistique. English and French with Equivalents in Dutch, German, Italian, Russian and Spanish, $2^{\text {nd }}$ revised Edition, Munich, New York, London, Paris: KG Saur 1988, 121.

6 ICA Code of Ethics. Available at: https://www.ica.org/en/ica-code-ethics. Last Accessed: 25.7. 2019.

7 Dan Stone: "The Memory of the Archive: The International Tracing Service and the Construction of the Past as History", in Dapim: Studies on the Holocaust 31, 2, 2017, 69-88, here 74. 


\section{Purpose-Related Document Acquisition and Autonomous Production of Source Material}

The world of archiving, based as it is on the principle of provenance, does not allow for the existence of a collections archive like the Arolsen Archives. The Arolsen Archives do not have a mandate to preserve all the records of specific bodies, but instead collect all the documents which seem important for their specific purpose, without paying any attention to institutional, regional or national boundaries. In addition, however - and here they come closer to the principle of provenance in their own peculiar way - they create sources which have their very own historical value and they do so on a large scale in the normal course of the very activities they pursue.

A search for the beginnings of the Arolsen Archives soon brings holdings to light which were not collected but were produced autonomously. Because many Nazi crimes were either not well documented or were not documented at all, the ITS already began to search for evidence in the late 1940s. For example, in order to collect evidence of the death marches endured by many concentration camp prisoners towards the end of the war, the ITS questioned thousands of local authorities and former prisoners, as well as examining burial sites and mapping the routes of the marches. ${ }^{8}$ The resulting collection and another similar one containing thousands of questionnaires with information provided by former prisoners about hundreds of places of detention were some of the first documentary holdings to be kept in Arolsen.

However, the large collections of documents which the Allies seized at the end of the war for tracing purposes or requisitioned from the Germans later on were not yet stored in Arolsen at the end of the 1940s. Instead, they were held by zonal tracing bureaus originally set up by the victors. Later, the ITS was to take over the bureaus in the American, British and French zones. But it was not until these bureaus stopped conducting active field searches for missing persons and documents in 1950, ${ }^{9}$ and transferred their holdings to Arolsen that an archive that was referred to as such came into being there. The objective, which was to conduct research on individuals quickly, had a decisive impact on the way the archive was organized and one of the reasons for this was that the task of providing confirmation of the history of persecution of specific indi-

8 Sebastian Schönemann: "Die Untersuchungstätigkeit des International Tracing Service zu Todesmärschen. Das Programm 'Attempted Identification of Unknown Dead”, in: Gedenkstättenrundbrief 159, 2011, $28-33$.

9 See the chapter by Christian Höschler and Isabel Panek in this volume. 
viduals for compensation claims or immigration proceedings was gaining importance at the same time.

First of all, the Concentration Camp Documents Section came into being at the beginning of the 1950's. It held valuable documents that the Allies and survivors had managed to rescue from Buchenwald, Dachau, Mauthausen, and other camps. In addition, this department also held all the other documents on concentration camp prisoners from any number of different sources - ranging from documents produced by top Reich authorities to post-war lists of liberated prisoners drawn up by survivors' initiatives. Up until 1952, the ITS also received hundreds of thousands of lists of foreign forced laborers from the zonal tracing bureaus which had been closed. These lists had been compiled by German authorities on the orders of the Allies during a large-scale foreigner tracing campaign which was started in 1945/46. Along with registration documents for foreign forced laborers from hundreds of different provenances, these documents formed the nucleus of the new Wartime Documents Section. At the end of 1952, the ITS received 30 tons of DP registration documents which had been produced by the Allies. This new material led to the creation of a third collection, the Postwar Documents Section. ${ }^{10}$

However, the two largest collections held by the Arolsen Archives were not collected, they were produced by the ITS itself. This seems to be characteristic of collections archives. The Central Name Index (CNI) deserves first mention here. This index contains references to the whereabouts of the victims of Nazi persecution derived from field searches, tracing inquiries, and the evaluation of the documents. Whenever material reached the ITS, person-related information was carded, and these reference cards were then sorted into the CNI in an alphabetic-phonetic order. The digitally available CNI, which was declared part of the world's documentary heritage by the UNESCO in 2013, includes more than 50 million references to approximately 17.5 million individuals. The CNI also provides researchers with a unique tool for conducting fast searches for individual persons across all the collections. ${ }^{11}$

The second collection of documents produced by the organization itself are the Tracing/Documentation Files ( $T / D$ files). There are almost three million of these files containing all the ITS correspondence on individual Nazi victims

10 ITS Executive Board: Monthly Report for the Month of August, 1953, 11.4/4595/ITS Archive, Arolsen Archives.

11 For a case study based on the CNI see Henning Borggräfe: "Die Rekonstruktion von Verfolgungswegen im NS-Terrorsystem: Eine Fallstudie zu Opfern der Aktion “Arbeitsscheu Reich”, in Henning Borggräfe (ed.): Freilegungen: Wege, Orte und Räume der NS-Verfolgung, Göttingen: Wallstein, 2016, 56-82. 
from the early post-war years on. Strictly speaking, this is nothing more than correspondence with users of the archive, which is not usually seen as a source of any great value. However, the situation is quite different here, as many inquiries contain descriptions of individual experiences which can be seen as ego documents. They also contain tens of thousands of pieces of information that are not to be found in any documents, either in Arolsen or elsewhere. Finally, the files are also a primary source which can inform personal and institutional debate on Nazi crimes and their consequences as well as providing a record of the changing social and political treatment of former victims of persecution. ${ }^{12}$

\section{The Shaping and Reshaping of Archival Holdings Over Time}

The ITS collected millions of documents on the subjects of detention, forced labor and displacement and organized them thematically in accordance with their purposes. The same organizational structure was established in all three sections of the archive: documents relating to individuals were stored in mixed card indexes which were sorted alphabetically. Documents containing lists of names were placed in thematic file series which were internally structured by subject matter, geography or chronology. Documents which did not contain any names were stored in separate file series, which were later brought together in the Historical Section. So the holdings were not organized according to the principle of provenance in Arolsen, but according to what is known as the principle of pertinence, which is given a bad press in specialist publications: "A principle, now rejected, for the arrangement of archives in terms of their subject content regardless of their provenance and original order."13

Structuring the holdings was a process which sometimes took decades and consisted of several different steps. The collection connected with the campaign to trace foreigners which dates back to $1945 / 46$ is a good example. The main objective of the campaign was to gather documents containing information on the fate of foreign forced laborers. In the winter of 1945/46, the four occupying pow-

12 This is also significant for the history of the experiences of marginalized groups subjected to persecution. See Henning Borggräfe and Hanne Leßau: "Die Wahrnehmung der NS-Verbrechen und der Umgang mit den NS-Verfolgten im International Tracing Service”, in Henning Borggräfe, Hanne Leßau and Harald Schmid (eds.): Fundstücke: Die Wahrnehmung der NS-Verbrechen und ihrer Opfer im Wandel, Göttingen: Wallstein, 2015, $23-44$.

13 Walne (ed.): Dictionary of Archival Terminologies, 121. 
ers issued orders to German municipalities, companies, the judiciary and the police, social insurance funds, hospitals, etc. to this end. These bodies produced hundreds of thousands of lists of foreigners as a result. Not only did the occupying powers define different specifications for the lists, they also pursued the campaign with varying degrees of intensity. ${ }^{14}$

All the material was supposed to be sent to the zonal tracing bureaus, which would then forward it to Arolsen. However, as a result of the incipient Cold War, hardly any lists were received from the Soviet zone. Similarly, the Soviet zonal tracing bureau was subsequently not integrated into the ITS. So while the campaign to collect documents was itself shaped politically, the holdings were shaped for a second time by the zonal tracing bureaus. The staff who worked there dissolved the provenances and resorted the material in accordance with the geographical origins of the lists and then in accordance with the nationality of the people. ${ }^{15}$ When it became apparent that there were gaps in the material, further tracing campaigns were launched in the late 1940s, mostly in the British zone, in order to complete the data. The new material was simply inserted into the existing structure. Decades later, the same thing happened at the ITS once again, this time in connection with material from archives in the former GDR and in western Poland that could be copied after the end of the Cold War. In the 1950s, once all the documents from the zonal tracing bureaus had been transferred to their new central location, the Wartime Documents Section at the ITS, they were reshaped again. The material from all the zones of occupation, which had already been sorted by district and then within the districts by nationality, was now sorted internally again according to specific list types which had been defined in the US zone for the purposes of the foreigner tracing campaign and which had been stamped on the documents. ${ }^{16}$ Finally, in the 1980s, the ITS moved parts of the collection to other parts of the archive because it held the view that they concerned other persecution complexes. This applied to lists of foreign inmates held in German police and judicial prisons, for example. ${ }^{17}$

Today, anyone looking for documents produced by a municipal authority for the foreigner tracing campaign will find individual parts of the lists and the as-

14 On the Foreigner Tracing Operation, see Sub-collection 6.1.1: Predecessor Organizations, Folders 74-79.

15 See for example Headquarters Search P.W. \& D.P. Division [British Zone], Library Section, 15.9.1947, 6.1.1/82515429-82515431/ITS Digital Archive, Arolsen Archives.

16 For example, there were specific list types for foreigners who had lived in the location during the war, who had died there during the war, or who still lived there when the lists were compiled. 17 Today such lists can be found in Sub-Collection 1.2.2.1: List Material Group Prisons \& Persecution. 
sociated cover letters at various different locations in the collection on the foreigner tracing campaign, but that is not all. They will find other parts of the lists scattered over other collections. Thus the documentary holdings of the Arolsen Archives as they are today have not only been shaped by those who created them in the first place, but also by different phases of archival processing that must be disclosed by collections archives and taken into account by those researchers who work with their collections. The signature systems of the ITS archive, which were changed repeatedly, are also part of the problem. Resorting and relocating documents has torn old signatures apart. ${ }^{18}$

\section{Political-Cultural Selection Processes in the Acquisition of Documents}

Collections archives broke with another core principle of archiving too: archival records are traditionally defined as being characterized by their uniqueness; unlike books in libraries, they are kept in one place only. ${ }^{19}$ However, the ITS and other collections archives did not only acquire original documents, they also copied millions of documents and sorted them into their collections. The acquisition of documents, whether by transferring originals, microfilming or later by creating digital copies, is probably the clearest expression of the political and cultural conditionality of the collections - because inevitably it was always a question of selecting what should and what should not be collected.

The ITS was involved in searching for and copying documents right from its inception. However, starting in the 1980s there was a sharp rise in new acquisitions which intensified still further after the end of the Cold War. At this time, it became apparent that the ITS archive contained no information on large numbers of persecutees from Central and Eastern Europe who were turning to Arolsen in their hundreds of thousands looking for proof of their persecution for compensation claims. As a result, ITS teams traveled through Germany and Europe to acquire, copy or microfilm documents. As early as in September 1989, ITS staff were able to film the death books of Auschwitz, for example. The Red Army had seized these documents in 1945. Soviet archives were inaccessible until 1989. By microfilming the documents in Moscow, the ITS gained access to evidence of

18 See Uwe Ossenberg: The Document Holdings of the International Tracing Service. Using the Digital Archives in the Context of their Creation and Evolution, A Guideline, Bad Arolsen: ITS, 2009, 47-63.

19 Reimann: "Grundfragen und Organisation des Archivwesens", 29. 
the deaths of thousands of victims of Nazi persecution in the Auschwitz concentration camp for the first time. ${ }^{20}$ But staff often had to work under pressure of time in difficult conditions when they microfilmed documents. They focused on recording the names. This is why the documents are often illegible and questions as to minimum archival standards for the quality of document copies in relation to the originals inevitably arise.

However, the selection processes which were applied in connection with document acquisition seem to be of even greater importance. The ITS did not usually acquire or copy complete archival holdings, but focused its interest instead on those people it saw as falling under its mandate - i.e. on foreign civilians and victims of Nazi persecution. Until well into the 2000s, the management of the ITS clung to an outdated definition of who was considered to be a victim of Nazi persecution which had been laid down by the West German authorities in the 1950s for use in connection with compensation claims. However, this definition came under massive criticism as a result of the social debates surrounding forgotten victims which arose in the early 1980s. Moreover, the staff, who often lacked historical knowledge, were only given a vague outline of the tasks they were to perform before they set off on these trips to acquire documents or began to inventory the new material. ${ }^{21}$ The process of securing the files from the Bonn Prison in 1983 is a case in point. The ITS often acquired files, some of them originals, shortly before they were due to be destroyed, as was the case here. Germany had no laws requiring authorities to hand over their files to a state archive at the time. After acquiring the documents, ITS employees took the original prisoner books and redacted the names of all the prisoners who did not belong to the narrowly defined target group. An associated card index was sorted, documents on prisoners of war were handed over to the WASt (German acronym of the German Office for the Notification of Next of Kin of the Former German Wehrmacht), and all the cards that did not appear to be relevant were destroyed. ${ }^{22}$

Far from being an isolated case, this was typical for the acquisition of documents pertaining to police and judicial prisons which presented staff with a heterogeneous group of subjects. The "Prisons/Persecution Group" sub-collection, which comprises several thousand folders, is full of lists which have been blacked out or rendered partially illegible by masking, as well as index cards or prison files that were sorted in accordance with the obsolete definition of

20 Borggräfe/Höschler/Panek (eds.): A Paper Monument, 150-153.

21 Interview by the authors with ITS Staff Members J.P. and C.S., 21.11.2018, ITS Object Collection, Arolsen Archives.

22 Borggräfe/Höschler/Panek (eds.): A Paper Monument, 156-157. 
the target group before the originals were acquired or before the documents were microfilmed. ${ }^{23}$ So document acquisition at the ITS does not only reveal the extent to which the ITS remained oblivious to public debate and new research on the persecution of social outsiders and other forgotten victims between the 1980s and the 2000s. It also begs the general question as to which criteria and which methods collections archives used when acquiring documents as well as to what extent the decisions made when selecting documents can be understood by users today.

\section{The Opportunities and Challenges of Digitization}

A fourth special feature of the Arolsen Archives, as they are now known, and of some other large collections archives is that they have become pioneers in the digitization of archival material since the 1990s. The reason for this is probably that there is a great deal of public interest in the subject of Nazi crimes. They pushed and continue to push ahead into a brave new world full of opportunities but also full of risks - and these too are to receive at least brief mention in the present chapter.

Digitization started at the ITS in the late 1990s to speed up the process of providing information from the archive. A backlog of hundreds of thousands of inquiries had built up in Arolsen by then. In 1997, the IT service provider Ossenberg \& Schneider presented an initial concept for a completely digital workflow for processing inquiries at the ITS. It covered digital research in the CNI and in all archival holdings. While space between the rows of shelves was limited, it was hoped that working at computer terminals would enable a much larger number of employees to carry out research in parallel. As had been recommended, the ITS and the service provider started by implementing partial solutions. The first major project was launched in 1998/99 and involved scanning the CNI. The major collections of the archive followed one by one. The process lasted up until the early 2010s. Since then, digitization has mainly focused on the large collection of the $T / D$ files. About $85 \%$ of the archival holdings have already been digitized. ${ }^{24}$

The focus on tracing missing persons meant that cataloguing was not primarily carried out at the level of holdings or files at the ITS, although progress

23 For another example, see Prisoners' book from Butzbach prison, 1934-1943, 1.2.2.1/ 11559710 - 11559840/ITS Digital Archive, Arolsen Archives.

24 Borggräfe/Höschler/Panek (eds.): A Paper Monument, 158-163. 
has recently been made on this. Instead, indexing was carried out at document level: names, dates and places, and sometimes also information on nationality, religion, etc. were entered into the archival database. Although some large gaps still exist, many holdings can be filtered very precisely according to a range of socio-biographical or geographical criteria. However, although this sounds like good news for users, it raises questions at the same time, because digitization is another form of shaping which involves only some content being made machine-searchable while other content is not.

An example of this is the collection of the 196,000 Care and Maintenance files of the International Refugee Organization (IRO). The DPs who still remained in occupied Germany used these files to apply for support between 1947 and $1951 .^{25}$ Researchers can not only search the collection by names, but also filter for people of a specific age, gender, place of origin, claimed nationality, or religion, or filters can be set for the camps where and dates when the applicants were registered. However, there is still a long way to go before the entire content of the files are machine-searchable. The following information is not yet accessible, for example: details of the whereabouts and workplaces of the DPs during the last 12 years, the reasons why they did not want to return to their home countries, their emigration destination or the decisions made by IRO officers on their applications. As was the case with the way the holdings were re-sorted at the physical level and with the selection processes involved in document acquisition, collections archives need to provide transparent information about the purpose of digitization and indexing, the method used and the criteria applied.

In principle, it would be possible to link documents of the same origin digitally and, in doing so, to reorganize collections archives virtually in accordance with the principle of provenance - in other words, to bring them into line with the prevailing norms of the archive world. The ITS took this path on a trial basis around $2010^{26}$, but quickly abandoned it due to the resource requirements. Indexing the holdings more deeply within the existing system of pertinence seems to make more sense as Optical Character Recognition (OCR) and clustering, plus a system of keywords on top of that, enable users to restore original connections themselves if required, without a new and separate digital structure having to be maintained parallel to the analog structure of the archive.

25 Henning Borggräfe: "Exploring Pathways of (Forced) Migration, Resettlement Structures, and DPs' Agency: Document Holdings and Research Potentials of the Arolsen Archives”, in Historical Social Research, forthcoming.

26 Karsten Kühnel: Usability of the Archives of the International Tracing Service (ITS), in Archivar 65, 2, 2012, 170-172. 
However, digitization not only opens up brand new prospects in connection with indexing, it also provides new possibilities for users in particular. This applies to the way access is organized. Thanks to the internet, access is increasingly becoming possible at the global level - as well as to the way users conduct research in the holdings - and the millions of indexed data sets are contributing to the creation of a brand new source. In future it will be necessary to explore the potential of these aspects and discuss their consequences in detail.

Historical developments in the area of research which is extraneous to the intended purpose of the archive and the thorny issue of access to collections archives will be considered in the second part of this chapter, using the history of the Arolsen Archives as an illustrative example.

\section{Research and Accessibility in Connection with Archival Collections}

Over the past three decades many conferences, discussion panels and publications, both in the world of archiving and in the humanities in general, have touched on the questions of what archives are, what function they have and whether they should play an active role in historical and socio-political debates in order to keep memory alive. ${ }^{27}$ There has been lively debate on the relationship between conventional archives and the public as well as exploration of the question of whether archives should be seen as part of the culture of remembering and the politics of history, or whether they are merely places where memory is managed:

[W] hether their character - to use Aleida Assmann's terminology - is that of a passive storage memory which secures so-called authentic memory more or less objectively so that it can be activated by others for the dialogue between the generations and transferred to con-

27 Within the fields of philosophy and cultural sciences, the term "archive" and the process of archiving are increasingly being used metaphorically, are understood as a cultural technique, less institutional. See Knut Eberling and Stephan Günzel (eds.): Archivologie: Theorien des Archivs in Philosophie, Medien und Künsten, Berlin: Kadmos, 2009; Markus Friedrich: Die Geburt des Archivs. Eine Wissensgeschichte, Munich: Oldenburg, 2013; Michel Foucault: Archäologie des Wissens, Frankfurt/Main: Suhrkamp, 17. edition, 2015; Rainer Hering and Dietmar Schenk (eds.): Wie mächtig sind Archive? Perspektiven der Archivwissenschaft, Hamburg: University Press, 2013. 
temporary functional memory if required, or whether they have to be seen at least to some degree as part of this functional memory which intervenes on a daily basis. ${ }^{28}$

These discussions about the interactive relationship between storage memory and functional memory touch on fundamental questions related to the accessibility and academic evaluation of archival holdings by external users as well as by archive staff. There is also the question of the extent to which archives can be "part of this functional memory which intervenes on a daily basis" by means of educational work, their own exhibitions, publications and events. The concept of opening up archives as a matter of principle to a historically interested public and the general access to cultural heritage which goes with this, which Jacques Derrida sees as being the "essential criterion" for "real democratization", emerged during the course of the French Revolution already. ${ }^{29}$ In the decades that followed, different rules of access developed in different countries and, in the twentieth century in particular, they began to be enshrined in laws. In Germany, the process of opening up state archives to the public went hand in hand with the professionalization of historical scholarship and the emergence of the profession of the archivist at the end of the nineteenth century. But it was only subsequently to the debates on informational self-determination which had been raging since the 1970s that laws were introduced at federal and state level between 1987 and 1997 to regulate questions of data protection and personality rights in the context of archiving and usability.

However, the ITS, known today as the Arolsen Archives, were and still are an international institution and as such are not subject to these German archive laws. Initially set up and managed by the Allies, in 1955 responsibility for the institution was transferred to the International Committee of the Red Cross (ICRC) and an International Commission (IC) was established to guarantee protection of the collections. The Bonn Agreements - which provide the basic legal framework for the ITS - defined the main tasks of the institution as follows:

[T]racing missing persons and collecting, classifying, preserving and rendering accessible to Governments and interested individuals the documents relating to Germans and non-

28 Hermann Rumschöttel: "Gedächtnisverwaltung oder Erinnerungskultur? Zur geschichtspolitischen Funktion der Archive”, in: Verband deutscher Archivarinnen und Archivare e.V. (VdA) (eds.): Lebendige Erinnerungskultur für die Zukunft. 77. Deutscher Archivtag 2007 in Mannheim, Fulda: Selbstverlag des VdA, 2008, 35.

29 Jacques Derrida: Dem Archiv verschrieben. Eine Freudsche Impression, Berlin: Brinkmann und Bose, 1997, 14-15. 
Germans who were interned in National-Socialist concentration or labor camps or to nonGermans who were displaced as a result of the Second World War. ${ }^{30}$

So it was that the core task of tracing and documenting came to be supplemented by the task of rendering the documents accessible to interested individuals. However, as was also the case with other early collections archives, this did not play a central role at first. Instead, tracing and documenting, the dominant activities at the time, took place primarily outside the public sphere and involved direct contact between the ITS and other tracing and documentation centers on the one hand and survivors and relatives of victims of Nazi persecution on the other. At the same time, during the early post-war period, neither contemporary historical writing nor public memory of the Nazi era paid much attention to the fates of individual victims of Nazi persecution. As a result there was no great interest in access to the ITS from either perspective.

The first factual evaluations of the documents were born of necessity. They were made by staff in connection with tracing activities, because knowledge about Nazi crimes was fragmentary at first and many pieces of information had to be collected and evaluated before they could be used. The collections were then opened up to survivors, academics and memorial initiatives who were able to search the holdings on site. This first phase of openness began at the end of the 1960s and lasted until the end of the 1970s. ITS staff also supported external projects during this period. At the beginning of the 1980s, the ITS archive gradually closed to the public and wound down most of its own historical projects. This launched a debate which was to last for over two decades centering on accessibility to the documents kept in Arolsen and involving controversial discussion of the main task and the intrinsic character of the institution. It seems that an interesting question to be explored in future might be on the one hand whether it is typical for collections archives to carry out their own intensive research in the context of their daily work (tracing activities, criminal prosecution etc.), and on the other hand, whether a difficult relationship to the issue of external access is also peculiar to collections archives, especially when remembering and remembrance are not their primary purposes.

30 Abkommen über die Errichtung eines Internationalen Ausschusses für den Internationalen Suchdienst, in: Bundesanzeiger, 7, 241, 14.12.1955, 3. 


\section{Knowledge Production at the ITS: Early Research Projects on Places of Detention and Nazi Crimes}

Up until the beginning of the 1980s, under the leadership of the Allies and under the first directors appointed by the ICRC, the ITS conducted a number of largescale evaluations which were based on the task of clarifying fates and which can be seen in retrospect as autonomous research projects. The search for missing persons and the process of providing information to state authorities in connection with the emigration of DPs or compensation, for example, went hand in hand with the acquisition and evaluation of documents. The ITS often lacked the specific knowledge needed in order to respond to the many inquiries it received. This included knowledge of particular places of detention and of complex crimes such as the death marches, the network of sub-camps belonging to the large concentration camp complexes or the medical experiments carried out on concentration camp prisoners. In order to gain knowledge in these areas, staff evaluated the documents on a thematic basis, conducted research at the sites of the crimes and produced contemporary sources by questioning survivors, for example. Questionnaires were the central research tool during this early period. The first questionnaire was circulated as early as in March 1946. In addition to questions on the construction and closure of places of detention, on the number of prisoners and the number of those who died, it also included questions on the whereabouts of the camp documents. ${ }^{31}$

At a meeting of national tracing bureaus held in Arolsen in the autumn of 1948, the participants agreed to draw up a comprehensive master list of all the places of detention in Europe to serve as a reference book for their daily work. ${ }^{32}$ As the international center for tracing and documentation, the ITS was commissioned to compile this list. In 1949, the ITS published the master list under the title Catalogue of Camps and Prisons in Germany and German-Occupied Territories. It was created on the basis of the so-called camp lists that had been drawn up previously by national tracing bureaus to determine the location of places of detention, as well as on an initial evaluation of documents confiscated from the Nazis, and on interviews with survivors. In addition to concentration

31 Amended Questionnaire on Camps, 6.1.1/82501260/ITS Digital Archive, Arolsen Archives. 32 Minutes of the Conference of the National Tracing Bureaux Representatives, 30.9-2.10.1948, 6.1.1/82516578/ITS Digital Archive, Arolsen Archives. 
camps and sub-camps, prisons and penitentiaries, this more than 480-page long catalogue also already listed places of civilian forced labor and ghettos. ${ }^{33}$

The knowledge gained from the evaluations was also recorded in special indexes, on maps, and later in a hanging file system in which originals or copies of documents on individual camps were kept. ${ }^{34}$ This collection was created in parallel to the archival collection and was managed by the Historical Section. Work on the documentation continued in this department until the early 1980s. The catalogue was last published in 1979 under the changed title Register Of Places Of Detention Under The Reichsführer-SS 1933-1945. ${ }^{35}$ However, many forced labor camps and ghettoes which had been listed in the earlier catalogue from 1949 were not included in this register. These omissions and the attending loss of knowledge should be seen in the context of Federal German compensation policy. From the 1950s on, the catalogue was no longer used exclusively by the ITS and other related tracing and documentation centers in order to determine the location of places of detention in connection with tracing inquiries. Instead, it had become a reference book which was used on a daily basis by Federal German compensation authorities. This also made the ITS the central point of contact for the authorities when it came to the evaluation and official recognition of individual camps in the context of compensation proceedings, despite the fact that the ITS was not an academic institution like the Munich Institute for Contemporary History, which was charged with rendering expert opinions connected with the Nazi period. ${ }^{36}$ Its expanded remit brought the work of the ITS into the discourse of the politics of history and the politics of dealing with the past in Germany. And there were repeated tensions with the German govern-

33 International Tracing Service: Catalogue of camps and prisons in Germany and German-occupied territories Sept. 1st, 1939-May 8th, 1945, Arolsen: ITS, 1949. Not until the middle of the 1990s did historical scholars begin to produce comprehensive "reference books" on places of detention during the Nazi era. The ITS was also involved in these projects. See the nine-volume work by Wolfgang Benz and Barbara Distel (eds.): Der Ort des Terrors. Geschichte der nationalsozialistischen Konzentrationslager, Munich: C.H. Beck, 2005-2009.

34 The indexes and maps were used in the day to day work of identifying locations in connection with the clarification of fates. During the digitization of the main holdings groups, the original documents were taken out of the over 12,000 hanging files and sorted into the newly created archival collection 1.1.0.7: Compilation of Information Regarding Various Detention Sites and Camps.

35 For a detailed description of the genesis of the catalogue of camps and prisons and the early testimonies which were used in order to produce it, see Susanne Urban: "Mein einziges Dokument ist die Nummer auf der Hand...” Aussagen Überlebender der NS-Verfolgung im International Tracing Service, Berlin: Metropol, 2018.

36 See https://www.ifz-muenchen.de/das-institut/gutachten/. Last accessed: 25.7.2019. 
ment, which wanted the catalog to be restricted to places of detention which the government had recognized in the context of compensation claims.

\section{Access to the Archival Holdings: Between Openness and Isolation}

Parallel to the work being done on the catalogue of camps and prisons and on the medical experiments conducted on concentration camp prisoners, ${ }^{37}$ it was possible for survivors, academics and memorial initiatives to carry out research in Arolsen from the late 1960s onwards. At the same time, the ITS also supported important memorial and research projects undertaken by other institutions, including the Memorial Book of the Federal Archives for the Victims of the Persecution of Jews in Germany. ${ }^{38}$ This phase of openness was closely linked to the management culture of Swiss national Albert de Cocatrix, who was the director at the time. He had come to Arolsen as the deputy director in 1955 and led the ITS from 1970 to 1977 . He was a staunch upholder of the way the organization had seen itself in the early days, i.e. as being in the service of the survivors, and he entered into intensive dialogue with victims' associations. At the same time, he took part in academic conferences where he presented the holdings of the ITS and promoted their use. At the VI International Medical Conference of the FIR in Prague in 1976, Cocatrix commented that document acquisition had contributed to the very positive development of the ITS over the past decades and that it had become "t h e documentation center for the period of persecution." 39 In line with this self-confident attitude, the annual reports of the 1970s proudly record visits from academics, students and memorial initiatives, such as the visit of the young academic Falk Pingel in 1974, who predominantly studied the collection of the Buchenwald concentration camp, or the research visits of Rüdiger Lautmann and Richard Plant, who were engaged in pioneering research on the persecution

37 In the 1960s, the ITS checked applications for compensation made by former concentration camp prisoners who had been victims of experiments. This was difficult at first because the documents held by the ITS were incomplete and hard to decipher. For this reason, collections of materials and evaluations on the subject of experiments on human beings in concentration camps were created, research was conducted in other archives and memorial sites, and contact was established with former prisoners. A total of 59 evaluations were produced.

38 For contextualization of the genesis of the Memorial Book within the work of the Federal Archives, see the chapter by Tobias Hermann in this volume.

39 Speech made by A. de Cocatrix at the International Medical Conference, Prague, 1976, 13 Soz 34/Library, Arolsen Archives. 
of homosexuals. Lautmann's team was even allowed to borrow documents on a temporary basis and take them to Bremen..$^{40}$

The ITS also cooperated with other institutions that were creating collections archives of their own and were involved in dealing with Nazi crimes, such as the Central Office in Ludwigsburg, with whom the ITS was in close contact from 1959 until the beginning of the 1980s. The two organizations exchanged documents and each allowed the other access to its own files. ${ }^{41}$ During his period as director, de Cocatrix applied a flexible interpretation of the four mandates of the ITS which were defined in the Bonn Agreements as follows: collection, ordering, preservation and rendering access to the documents. However, the broad definition applied to accessibility led to conflicts with the ICRC, the governing body of the ITS, because of its intrinsic commitment to humanitarian ideals and neutrality. Seen from this perspective, the humanitarian mandate was only concerned with tracing missing victims of Nazi persecution, clarifying fates and documenting the persecution of individual victims.

Cocatrix's successor Philipp Züger implemented this narrow interpretation of the mandate consistently from 1978 onwards. Together with his deputy CharlesClaude Biedermann, who took over from him as director in 1985, they gradually closed the archive both to the interested public and to researchers, wound down most of the historical projects run by the ITS and discontinued support for the criminal prosecution of former Nazi perpetrators. During the course of these changes, the Historical Section was renamed the General Documents Section, a more neutral sounding name. On the one hand, Züger and Biedermann justified this about-face by invoking the ICRC's self-image as a neutral, humanitarian institution as well as a narrower interpretation of the four mandates of 1955 . There was no longer any talk of "rendering access" to the documents. From then on, the documents were to be "reviewed" instead. On the other hand, they also employed arguments based on issues of data protection and personality rights, which had gained political and social significance in the Federal Republic of Germany in the context of debate surrounding informational self-determination. At the ITS, this new sensitivity with regard to handling personal data affected data acquisition in the 1980s most of all. Social security authorities and many companies became increasingly cautious and were only willing to release documents if the ITS would not pass them on to third parties - such as critical historians whose research was putting increasing pressure on companies as far

40 11/45582/ITS Archive, Arolsen Archives. See Rüdiger Lautmann: Seminar: Gesellschaft und Homosexualität, Frankfurt/Main: Suhrkamp, 1977; Richard Plant: The Pink Triangle. The Nazi War Against Homosexuals, New York: Holt, 1988.

41 See the chapter by Kerstin Hofmann in this volume. 
as questions of compensation were concerned from the mid 1980s on. The isolation of the ITS from the public and from the world of historical scholarship was supported by the International Commission (IC) of the ITS, the ICRC and the Federal Government. At its annual meeting in 1984, the IC decided that document acquisition and the humanitarian mission should be given priority and voiced its support for the ITS director's restrictive attitude to academia. The Belgian representative to the IC, Fernand Erauw, made the following statement: "Our objective is now [...] to obtain all the information we can about the past." For this reason, the principle that "researchers are not allowed to research in the ISD [ITS] archives from now on" had to be upheld. ${ }^{42}$

This policy of isolation weighed even more heavily because the 1980s were a time of intense debate about the Nazi past in West German society. Under the motto dig where you stand, memorial initiatives explored local aspects of Nazi history that had sunk into oblivion and expressed solidarity with forgotten victims. They accused the ITS of actively preventing a critical analysis of Nazi history and of "protecting the perpetrators" and they protested against the isolation of the ITS archive. The path which led to the archive reopening its doors to the public in 2007 was long and stony and involved many different parties. In the 1980s, protest came predominantly from within Germany. From the mid-1990s, protests became both more vigorous and more international: survivors' associations, the directors of various concentration camp memorials, researchers and committed individuals published numerous resolutions demanding access to the documents which were kept in Arolsen. At the same time, they harshly criticized the long waiting times for information needed in connection with pension and compensation claims. Most of these claims concerned victims of Nazi persecution from Central and Eastern Europe and they had been piling up since the late 1980s. Four resolutions will serve as examples illustrating the broad spectrum of the protests: in 1995, more than 50 academics signed a resolution at the international conference on The National Socialist Concentration Camps 1933-1945. Development and Structure in which they demanded access to the holdings and offered assistance from concentration camp memorials in fulfilling the humanitarian mission. At the same time, over 200 academics from the fields of the humanities and social sciences, trade unionists, politicians and publicists formulated the same demands in a resolution initiated by Frank-Uwe Betz. One year later, the Amicale Internationale $K Z$ Neuengamme, the umbrella organization of the former prisoners of the Neuengamme concentration camp and their relatives, who had cooperated closely with Albert de Cocatrix three decades ear-

42 Minutes of the IC meeting, Bonn, 10.5.1984, 12.2.17.1/159/ITS Archives, Arolsen Archives. 
lier, published a statement in which it emphasized that research into Nazi crimes was also an "act of intangible recognition." For this reason, they too considered access to the ITS archive to be indispensable. And the two other major Holocaust collections archives, the USHMM and Yad Vashem, which argued for opening the archive in their function as advisory members of the IC, also spoke out in 1996 when they presented a joint Proposal for Opening the ITS Archive. ${ }^{43}$ In this proposal, they suggested that the holdings of the ITS be fully digitized and made available to the member states of the IC. Their intention was to avoid lengthy debates on data protection in the member states of the IC and make the digital copy available to the public in accordance with the data protection regulations of their countries.

In view of the massive public protest and accompanying scandal in the German media, the topic of "accessibility" was a constant point of discussion at the annual meetings of the IC in the years that followed. In consequence, there was an initial partial opening in 1996, which applied to the so-called non-personal general documents, and in 1998, the IC resolved to reopen the ITS archive, but emphasized the overriding priority of the humanitarian mission and with it the necessity of dealing with the backlog of inquiries. ${ }^{44}$ Over the years that followed, the topic was discussed repeatedly by the IC, examined at greater depth by various working groups, and deferred on numerous occasions during the same period. There was disagreement and ignorance about data protection issues and possible rules of access because, as an international institution, neither the national archive laws of Germany nor the archive laws of any of the federal states could be applied to the ITS, and comparison with the legal position of national Red Cross societies also proved difficult. At the same time, there was also disagreement as to whether the collections of the ITS could even be described as archives and whether the holdings should be transferred to other institutions, such as the archives of the concentration camp memorials, the Federal Archives or the Holocaust Memorial in Berlin, which was under development at the time.

The renewed opening of the archive in 2007 was largely due to the work of historian Paul Shapiro from the USHMM, who continuously increased political and media pressure at international level from 2001 onwards. Not only did he

43 11.16/1296-1297/ITS Archive, Arolsen Archives; A selection of resolutions can also be viewed in the online exhibition "A Paper Monument: The History of the Arolsen Archives", see www. arolsen-archives.org/exhibition. For a chronological overview, see also: Frank-Uwe Betz: "Verdrängung ex ante. Über die Abwehr des Zugang zum ITS-Archiv”, in Mittelweg, 36, 1998, 41- 48. 44 Researchers tried to circumvent this isolation by going to Yad Vashem to view the ITS holdings that had been microfilmed in Arolsen in the 1950s and integrated into the Yad Vashem collection. See the chapter by Zvi Bernhardt in this volume. 
show great persistence in putting the topic on the agenda of the annual IC meetings year after year, he also sought allies among politicians, researchers and survivors. ${ }^{45}$ His efforts to sensitize the members of the Task Force for International Cooperation on Holocaust Education, Remembrance and Research, which was renamed the International Holocaust Remembrance Alliance (IHRA) in 2013, to the issue of access to the documents held in Arolsen are a good example of his approach. As members of the Task Force, nine member states of the IC which were opposed to opening up access to the ITS archive had actually committed themselves to campaigning for free access to archives that preserve Holocaust related documents by signing the Stockholm Declaration of 2000: "We share a commitment to throw light on the still obscured shadows of the Holocaust. We will take all necessary steps to facilitate the opening of archives in order to ensure that all documents bearing on the Holocaust are available to researchers." ${ }^{46}$ At the same time, Shapiro arranged for the publication of a number of newspaper articles and invited the then German Minister of Justice, Brigitte Zypries, to a meeting and a press conference in Washington one month before the IC convened in April 2006. At the press conference, Zypries announced that the German government was now committed to providing access to the ITS archive and would take steps to accelerate the process. In May 2006, the IC voted unanimously to reopen the collections in Arolsen to the interested public and researchers.

As well as deciding to open the ITS archive, the IC also adopted the proposal that USHMM and Yad Vashem had put forward in the mid 1990's already to hand over digital copies of the ITS archive to all the member states of the IC. This means that today, the digital ITS archive is additionally held by seven partner institutions of the Arolsen Archives which are known as copyholders. ${ }^{47}$ As a consequence of the opening, the ICRC withdrew from the management of the ITS in 2012. The International Commission took over responsibility for the ITS itself and pushed ahead with a new course of intensified modernization, openness and networking. Since 2015 this has resulted in more and more entire collections

45 For a chronological overview of the efforts he undertook, see Paul A. Shapiro: Opening the Archives of the International Tracing Service (ITS) How did it happen? What does it mean? Available at: https://vwi.ac.at/images/Downloads/SWL_Reader/Shapiro/SWL-Reader-Shapiro.pdf. Last accessed: 12.7.2019.

46 Available at: https://www.holocaustremembrance.com/index.php/stockholm-declaration. Last accessed: 12.7.2019.

47 See https://arolsen-archives.org/suchen-erkunden/\#faq. Last accessed: 1.8.2019. 
gradually also being published in an online archive. All the documentary holdings from concentration camps and ghettoes can now be viewed online. ${ }^{48}$

The ITS thus left the extreme isolation it had been in since the beginning of the 1980s and is now open to users all over the world. This profound transformation can also be seen as a typical feature of collections archives. As well as making no distinction between originals and copies when they integrate documentary holdings into their collections, they also tend to share documentary holdings in their entirety with other institutions. At first this was done to promote the core task of tracing and documenting victims of persecution - today the aim is to make the holdings available to a wider public. Unlike conventional archives, collections archives evidently do not really see themselves in the role of the sole repository of authentic memory. In addition to the preservation of cultural heritage for current and future generations, they consider their core tasks to be the provision of easy and, ideally, global access and, in connection with this, the promotion of active learning and remembering from and with archive documents. Especially if they have not recently been integrated into state archives, the collections archives that were established for specific purposes after 1945 in response to Nazi crimes and the turmoil of the Second World War must be seen much more as "part of this functional memory which intervenes on a daily basis" than conventional archives. However, because many conventional archives are also currently working on providing easier access and showing greater social engagement, it remains to be seen to what extent this development will further reinforce the special role of collections archives or whether collections archives are perhaps playing a pioneering role in a general trend here, which will lead to a harmonization in the world of archiving in the medium term.

48 Available at: https://collections.arolsen-archives.org/search/. Last accessed: 12.7.2019. 
